\title{
Low abundance and skewed population structure of the whelk Stramonita haemastoma along the Israeli Mediterranean coast
}

\author{
G. Rilov ${ }^{1, *}$, Y. Benayahu' ${ }^{2}$ A. Gasith ${ }^{1}$ \\ ${ }^{1}$ Institute for Nature Conservation Research and ${ }^{2}$ Department of Zoology, George S. Wise Faculty of Life Sciences, \\ Tel-Aviv University, Ramat-Aviv, Tel-Aviv 69978, Israel
}

\begin{abstract}
Stramonita (=Thais) haemastoma (Kool, 1987), a relatively large predatory snail found in rocky littoral ecosystems, can attain densities of hundreds of individuals per $\mathrm{m}^{2}$ in warm temperate coasts of the western Atlantic. It has also been reported as common along the Israeli Mediterranean coast; however our preliminary observations there suggested low abundances of this species. We measured densities of the whelk and those of its major potential prey by quadrat and belt transect (plots) methods, supported by underwater photography when applicable. Our study demonstrates that indeed densities of $S$. haemastoma along the Israeli Mediterranean coast are very low $\left(<0.5 \mathrm{~m}^{-2}\right)$ in most habitats and locations, with the exception of some midlittoral habitats (density of ca 7 snails $\mathrm{m}^{-2}$ ) where food and shelter are abundant. Food is probably not a limiting factor in most midlittoral habitats, and the low abundance of $S$. haemastoma is likely to be associated with scarcity of shelters and high risk of dislodgment or of desiccation. The population structure of the whelks is skewed to large snails. Small individuals were absent throughout the entire $5 \mathrm{yr}$ of the study, while mean whelk size increased during this period. These results suggest impaired recruitment of whelks in recent years. Assuming that $S$. haemastoma was once abundant along the Israeli coast, it is possible that the following contemporary changes which occurred in the Levant basin may have affected whelk reproduction and/or juvenile survival rates and therefore may also explain the low recruitment rates: (1) diminished seasonal reduction in salinity due to the damming of the Nile; (2) unregulated use of tributyltin-based antifouling paints in Israel, which may impair reproduction through imposex; and (3) massive periodic appearance of a new plankton feeder along the Israeli coast, the Indo-pacific jellyfish Rhopilema nomadica, which may prey on the snail larvae.
\end{abstract}

KEY WORDS: Stramonita haemastoma $\cdot$ Mediterranean $\cdot$ Levant $\cdot$ Population structure $\cdot$ Distribution

\section{INTRODUCTION}

Understanding the within- and between-site variation in the benthic community structure on rocky shores has challenged marine ecologists in recent years, yet the factors producing the differences in the observed patterns are not fully understood (Paine

\footnotetext{
*Present address: Duke University Marine Laboratory, Nicholas School of the Environment, Duke University, 135 Duke Marine Lab Road, Beaufort 28516, North Carolina, USA.E-mail: gr3@duke.edu
}

1994, Little \& Kitching 1996, Menge et al. 1997). It is well established, however, that physical conditions such as tide fluctuations, wave action, salinity and temperature, as well as food-web interactions, affect species distribution and community structure in rocky littoral ecosystems (e.g., Menge 1978, Menge \& Lubchenco 1981, Underwood 1985, Menge et al. 1994, Paine 1994, Wootton 1994, Navarrete 1996). The Israeli coast, which forms part of the easternmost Mediterranean Levant basin, is characterized by low nutrient levels (Goldman 1995, Robarts et al. 1996), relatively high salinity (38 to $39 \%$ ) and warm waters $\left(15\right.$ to $30^{\circ} \mathrm{C}$ : 
Por 1978). Tidal fluctuations are minor (mean of 25 to $30 \mathrm{~cm})$, irregular, and often concealed by wave action (Safriel 1966). This combination of physical conditions together with a unique structural and biological formation of vermetid rocky reefs (Safriel 1966, 1974), makes the Israeli rocky coast an intriguing environment for scientific investigation. However, the macrobenthic community in this ecosystem, including predators, and the prevailing regulating factors have been so far poorly studied. From the conservation perspective, such information is of special interest due to the invasion of a great number of species from the Red Sea to the Mediterranean (Lessepsian migration: Por 1978) and the potential influence on the coastal environment of the intensive urbanization along the Israeli shore.

Stramonita (= Thais) haemastoma (Kool 1987) is a relatively large predatory whelk (up to ca $80 \mathrm{~mm}$ shell length) found in rocky littoral habitats in warm temperate waters from the western side of the Atlantic Ocean to the Mediterranean Sea in the east (Butler 1985, Barash \& Danin 1992). In contrast to the Western Atlantic sub-species $S$. haemastoma floridana from the Gulf of Mexico, which has been studied extensively as a predator on the local oyster populations (see review by Butler 1985), no biological or ecological information exists on its Mediterranean conspecific. The former, was reported to reach maturity at the age of 8 to $12 \mathrm{mo}$ and to spawn annually from April to August (Butler 1985, Roller \& Stickle 1988, 1989), with its intracapsular development extending over a period of a few weeks (D'Asaro 1966, Butler 1985). In Louisiana, S. haemastoma floridana and $S$. haemastoma canaliculata are euryhaline and usually found in salinities of 15 to $35 \%$ (Gunter 1979), but laboratory experiments have shown them to have an even wider tolerance of 3.5 to $54.8 \%$ (Liu 1990). Their optimum conditions for activity (feeding) in the laboratory were found to be $30^{\circ} \mathrm{C}$ and $25 \% \mathrm{~S}$ (Garton \& Stickle 1980, Stickle 1985). Both the density and size structure of $S$. haemastoma floridana from the Gulf of Mexico exhibit seasonal changes and vary among locations and with physical conditions (Brown \& Richardson 1987, Brown 1997). In intertidal habitats they can attain densities of tens to hundreds of individuals per $\mathrm{m}^{2}$ (Butler 1985, Richardson \& Brown 1990).

Barash \& Danin (1992) reported that Stramonita haemastoma is common along the Israeli Mediterranean coast. Safriel et al. (1980) have stated that in observations conducted in the 1960s to 1970 s this species was seen in large numbers in several midlittoral habitats and appeared to have affected the distribution of mussel beds of the indigenous species Mytilaster minimus. These observations suggest that $S$. haemastoma was once a keystone species, at least in some habitats. We were therefore intrigued by the findings of our preliminary survey (April 1994) that this whelk was rather rare in rocky habitats of the mid and shallow infralittoral zone and, furthermore, that juveniles were absent. We hypothesize that the low abundance of $S$. haemastoma may reflect: (1) reduced food availability associated with the ultraoligotrophic nature of the eastern Mediterranean basin (Robarts et al. 1996); (2) limitation resulting from extreme physical conditions such as wave exposure or desiccation; or (3) anthropogenic influences (e.g., pollution and changes in biotic or abiotic conditions) that reduce the reproductive output and/or lower juvenile survival. Thus, we set the following objectives: (1) to examine the abundance and size structure of the population of $S$. haemastoma along the Israeli coast; (2) to assess whether food might be a limiting factor for the whelk abundance; (3) to study the patterns of spatial distribution which might reveal physical constraints on abundance; and (4) to assess whether or not anthropogenic changes in the eastern Mediterranean could possibly have affected the whelk's populations in recent years.

\section{METHODS}

Study sites. The Israeli shore (190 km long) is exposed to strong wave action caused by the prevailing westerly winds. Information on the maximum wave heights were extracted from data of the Israeli Meteorological Service (1995 to 1997), which were based on measurements of wave height 8 times a day from a buoy approximately $2 \mathrm{~km}$ west of Haifa (north-central Israel). A maximum wave height of $>1 \mathrm{~m}$ was recorded in $50 \%$ of the measurements, and in about $80 \%$ of the measurements it was $>0.5 \mathrm{~m}(\mathrm{n}=8760)$.

The Israeli rocky areas are mostly comprised of low midlittoral flat vermetid sandstone or limestone platforms, a formation restricted to warm temperate or sub-tropical seas (Tzur \& Safriel 1978). Nearshore rocky formations usually extend to a maximum depth of 6 to $7 \mathrm{~m}$, and the walls of most sandstone platforms to a depth of 4 to $5 \mathrm{~m}$. From the base of the rocky platforms seaward, the bottom levels off, and is usually sandy or of horizontal bedrock. In the present survey 11 sites along the Israeli coast were studied (Fig. 1): 2 in the north (Akhziv and Shiqmona); 6 in the central region (HaBonim, Mikhmoret, the Herzelia marina breakwater, Tel-Baruch, the Tel-Aviv marina breakwater and Bat-Yam); and 3 in the south (Palmachim, Ashdod and Ashqelon). At selected sites several habitats were investigated, including midlittoral platforms of different shapes, beachrock and horizontal flats with rough surfaces and many incisions and holes (termed herein 'incisioned-rock'). In the infralittoral we examined shallow lagoons, vertical surfaces (walls), boul- 
ders and bedrock. In the Bat-Yam site, a whelk population was located in 1996 on the walls of a small shallow canyon (termed herein 'gully walls'). In Akhziv the availability of shelter, expressed as density of holes and crevices per $\mathrm{m}^{2}$, was compared between 2 incisioned-rock habitats ( $\mathrm{a}$ and $\mathrm{b}$ respectively, $\mathrm{n}=10$ in each) and a nearby sandstone platform ( $\mathrm{n}=60$ ).

Whelk density and spatial distribution. To examine possible seasonal changes in the population, we monitored whelk density every 1 to 3 mo from June 1995 to February 1998 in the midlittoral incisioned-rock in Akhziv, and from April 1996 to August 1997 in the infralittoral population in Bat-Yam. Follow-up observations were conducted in October 1998 and 1999 at the Akhziv site. For comparison among sites and habitats, the population density of the whelks was assessed during September to November 1996, when the species appeared to be most abundant (see 'Results'). The results reported here represent daytime counts recorded under calm sea conditions. In addition, limited qualitative observations were made at night. Midlittoral and infralittoral habitats were examined on foot and by SCUBA diving, respectively.

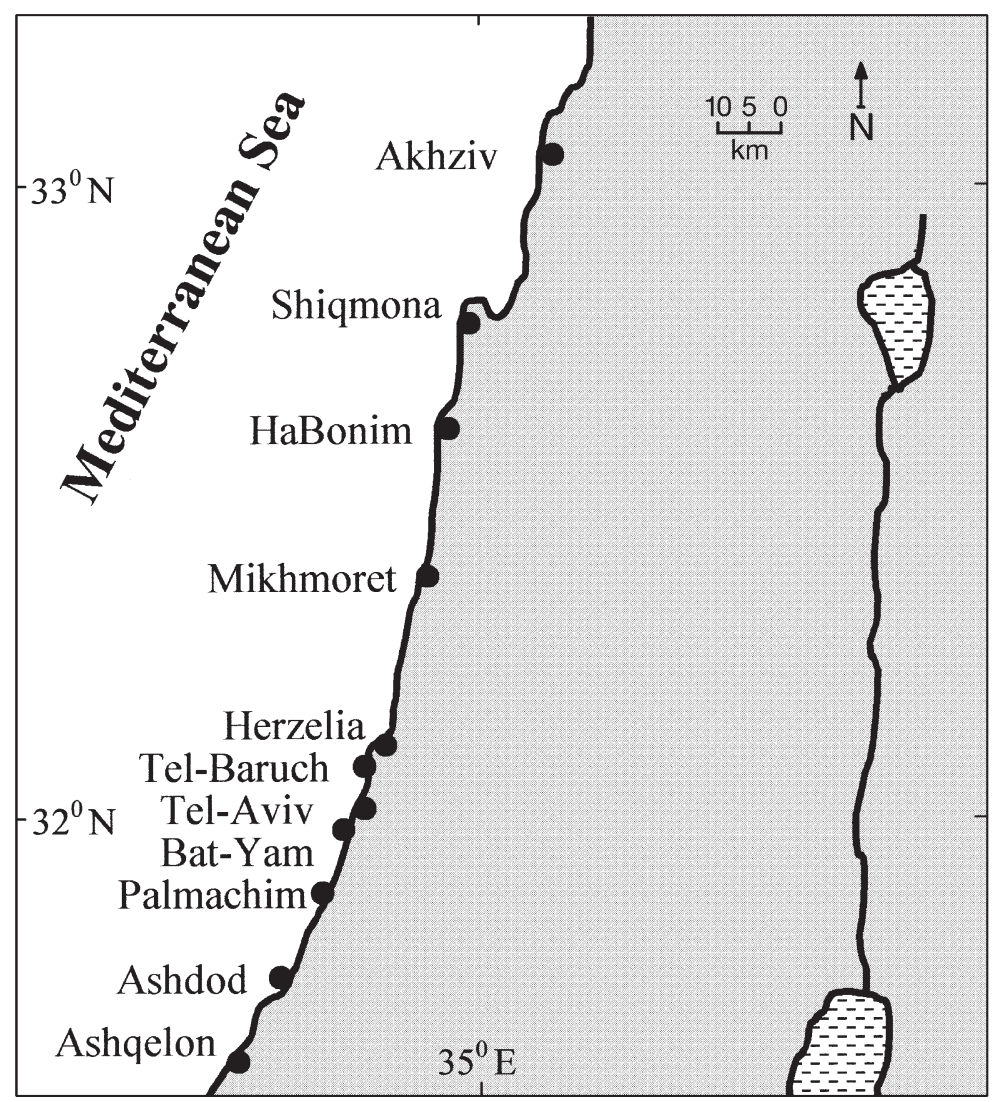

Fig. 1. Study sites along the Israeli Mediterranean coast Since the snail was very rare in some habitats and relatively common in others, we had to sample abundances using different plot sizes. When the snails appeared relatively abundant (i.e., $>0.5 \mathrm{~m}^{-2}$ ) they were counted using $1 \times 1 \mathrm{~m}$ quadrats, and when rare, along $10 \times 1 \mathrm{~m}$ plots. Densities are given with standard deviations in the text, tables and in Figs 4, 6 \& 8, and with standard errors in Figs 2, 3, 5 \& 7.

The spatial distribution of the whelks was determined in populations with densities $>0.5$ snails $\mathrm{m}^{-2}$ during September and October 1996, and in one site (Bat-Yam) also in August 1996, when abundant egg capsules were observed. Calculations were made using the Morisita index for sample dispersion (Morisita 1959) as follows:

$$
I_{\delta}=\frac{q \sum n_{i}\left(n_{i}-1\right)}{N(N-1)}
$$

with $F$ calculated as:

$$
F_{0}=\frac{I_{\delta}(N-1)+q-N}{q-1}
$$

where $q=$ number of quadrats, $n_{i}=$ number of snails in the $i$ quadrat, $N=$ total number of snails in the sample,

and $I_{\delta}=$ the Morisita index. Significance was determined by comparing $F_{0}$ to the critical value in the $F$ distribution $\left(F_{\infty}, q-1\right)$.

Whelk population size structure. The shell length of Stramonita haemastoma was measured in situ to the nearest $0.1 \mathrm{~mm}$ using a caliper. For comparison of sizes in different sites and habitats we used the records obtained during September to November 1996. To assess changes in whelk size during the study period, we measured whelks during 1994 to 1997 and in October 1998 and 1999 in a fixed $1 \times 10$ m incisioned-rock midlittoral plot in the Akhziv site, and during 1996 to 1997 in a $2 \times 20 \mathrm{~m}$ fixed plot in the Bat-Yam gully-wall site. Additionally, within-site and among-habitat differences in mean size were assessed by comparing 2 midlittoral incisioned rocks and infralittoral boulders in Akhziv, and a bedrock and the gully-wall infralittoral habitats in Bat-Yam. Differences in mean size and mean whelk density among populations was tested using 1-way ANOVA.

Food availability. Based on information on the feeding habits of Stramonita haemastoma (Butler 1985, Brown \& Richardson 1987, Spence et al. 1990), we assumed that along the Israeli shore this species feeds 


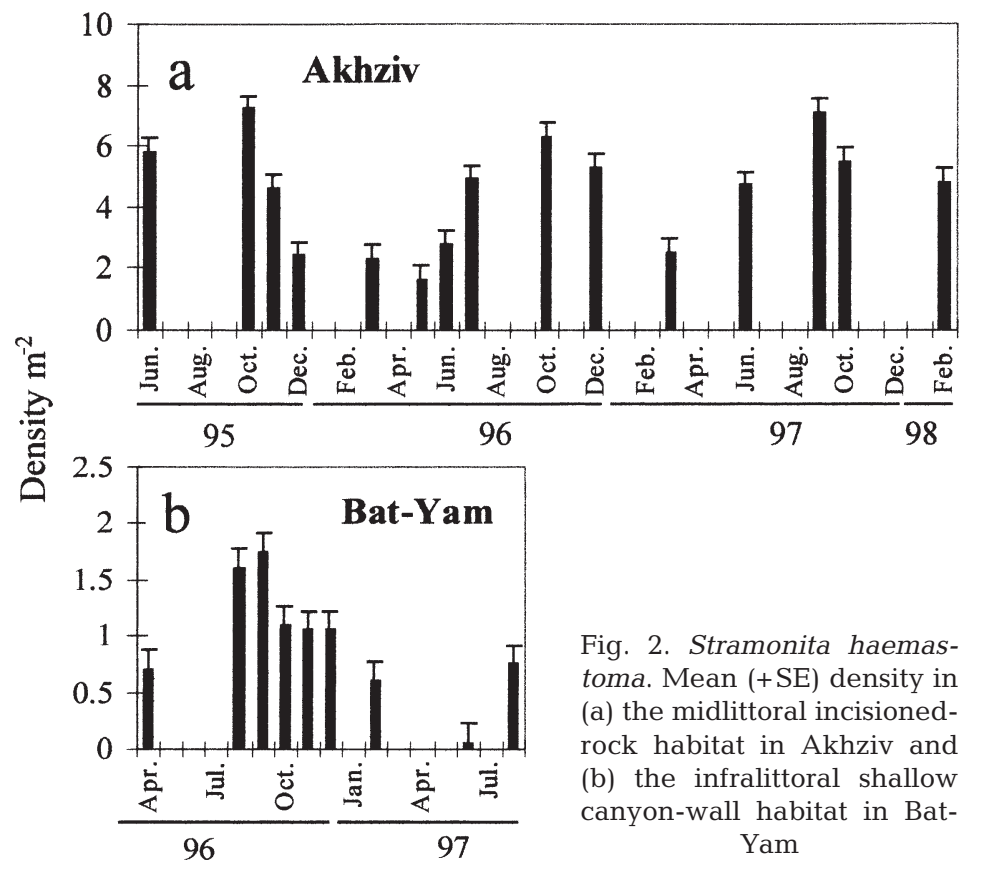

unpubl. data) The densities of the potential food items were determined during May 1995 in selected sites and habitats in the lower midlittoral and shallow infralittoral zones in quadrats corresponding in size to prey abundances (Table 1). In Akhziv, density was measured on 3 platforms $(A, B, C)$. Where prey abundance was relatively high $\left(>10\right.$ ind. $\mathrm{m}^{-2}$ ), eight $10 \times 10 \mathrm{~cm}$ randomly selected sub-quadrats were chosen within a $1 \times 1 \mathrm{~m}$ quadrat, and the food items, except for mussels within mussel beds, were counted. Since it was not feasible in the field to determine mussel density within a mussel bed, 5 randomly chosen $10 \times 10 \mathrm{~cm}$ quadrat samples were removed from each site where mussel cover was $100 \%$ and later counted in the laboratory. Following are the mean number of mussels $( \pm \mathrm{SD})$ per $100 \mathrm{~cm}^{2}$ mussel bed in each site: Akhziv incisioned-rock $=$ $894 \pm 228$; Akhziv platform $\mathrm{A}=159 \pm 59$; Akhziv platform $\mathrm{B}=151 \pm 62$; Akhziv plat-

on mussels (mainly Mytilaster minimus and Brachidonthes pharaonis), barnacles (mainly Chtamalus stellatus in the midlittoral, and Balanus perforatus in the infralittoral) and limpets (Patella caerulea). A preliminary study confirmed this assumption and further showed that a local vermetid gastropod, Vermetus triquater, is also preyed upon by the whelk (authors'

Table 1. Sampling design of potential food items of Stramonita haemastoma and quadrat size at the different sites and habitats. M: midlittoral; I: infralittoral; DC: direct count; P: photography

\begin{tabular}{|c|c|c|c|c|}
\hline \multirow{2}{*}{$\begin{array}{l}\text { Site } \\
\text { Zone }\end{array}$} & \multirow{2}{*}{ Habitat } & \multicolumn{3}{|c|}{$\longrightarrow$ Quadrat size } \\
\hline & & $\begin{array}{c}10 \times 10 \mathrm{~cm} \\
(\mathrm{DC})\end{array}$ & $\begin{array}{c}1 \times 1 \mathrm{~m} \\
(\mathrm{DC})\end{array}$ & $\begin{array}{c}18.5 \times 13 \mathrm{~cm} \\
(\mathrm{P})\end{array}$ \\
\hline \multicolumn{5}{|l|}{ Akhziv } \\
\hline M & Platforms & $x$ & & \\
\hline I & Incisioned-rocks & $x$ & & \\
\hline I & Boulders & $x$ & & \\
\hline I & Platform wall & & & $x$ \\
\hline \multicolumn{5}{|c|}{ HaBonim } \\
\hline M & Platform & & $x$ & \\
\hline M & Incisioned-rocks & $\times$ & & \\
\hline I & Platform wall & & & $x$ \\
\hline \multicolumn{5}{|c|}{ Mikhmoret } \\
\hline M & Platform & $x$ & & \\
\hline I & Bedrock & & $\times$ & \\
\hline \multicolumn{5}{|c|}{ Bat-Yam } \\
\hline M & Platform & $x$ & & \\
\hline I & Gully walls & & & $x$ \\
\hline I & Bedrock & & $x$ & \\
\hline
\end{tabular}

form $\mathrm{C}=448 \pm 126$; and Bat-Yam platform $=415 \pm 102$. These values were used to extrapolate mussel densities in areas of the bed where the percentage of mussel cover was $<100$. When potential prey abundance was low $\left(<10\right.$ ind. $\left.\mathrm{m}^{-2}\right)$, it was counted in $1 \times 1 \mathrm{~m}$ quadrats. When wave action restricted direct counts in infralittoral walls, we used underwater photographs taken along a line transect at 1 to $2 \mathrm{~m}$ depth, in $1 \mathrm{~m}$ intervals, using a Nikonos V camera equipped with a close-up frame $(18.5 \times 13 \mathrm{~cm})$. These were later analyzed in the laboratory by projecting them onto a calibrated grid and counting the prey items. Barnacle size was estimated from their orifice length measured from the photographs. In all locations and habitats the density data obtained by the different sampling methods, were standardized to a unit area of $100 \mathrm{~cm}^{2}$.

\section{RESULTS}

\section{Whelk density and spatial distribution}

Density of Stramonita haemastoma fluctuated seasonally (Fig. 2) and was highest during autumn (September and October) and lowest during late winter (February and March), except for an unusually low density recorded in June 1997 at the infralittoral site in Bat-Yam (Fig. 2b). Whelk density also varied among locations, habitats and depths during autumn (1996). The highest density of about 6.5 ind. $\mathrm{m}^{-2}$ was found in the incisioned-rock habitat (Akhziv site: Fig. 3a). There the whelks were usually found in burrows, crevices and depressions surrounded by dense mussel beds. An 
order of magnitude lower density $(0.67 \pm$ $1.2 \mathrm{SD}$ ind. $\mathrm{m}^{-2}$ ) was recorded on beachrocks at a site near Tel-Aviv (TelBaruch), where mussels were usually found in small patches. On midlittoral platform flats densely covered by either mussels or algae, the whelks were extremely rare $\left(<0.1\right.$ ind. $\left.\mathrm{m}^{-2}\right)$, or even absent (Fig. 3a,b,c,e). In incisioned-rock sites $a$ and $b$ at Akhziv, the average number of holes and crevices with an opening area $>100 \mathrm{~cm}^{2}$ was greater by about an order of magnitude than that found on the nearby platforms (Table 2). Low whelk densities were also found in the infralittoral in the upper 1 to $2 \mathrm{~m}$ of platform walls and breakwaters (Fig. 3). In contrast, higher whelk densities were found at similar infralittoral depths in protected niches such as the inside walls of a small shipwreck (up to 7 ind. $\mathrm{m}^{-2}$ : HaBonim site, Fig. 3b), in holes surrounded by macroalgae (up to 4 ind. $\mathrm{m}^{-2}$ : HaBonim, Fig. 3b) or by mussels (up to 16 ind. $\mathrm{m}^{-2}$ : Bat-Yam site, Fig. 3e). Densities varying by an order of magnitude (mean $=0.2$ to $1.5 \mathrm{ind}$. $\mathrm{m}^{-2}$ ) were recorded on vertical surfaces of walls, large boulders and on the seaward side of marina breakwaters at depths of $>1$ to $2 \mathrm{~m}$ (Fig. 3). Lower densities $\left(<0.1\right.$ ind $\left.\mathrm{m}^{-2}\right)$ were recorded at this depth range on horizontal surfaces (e.g., bedrocks: Fig. 3 b,c,e) and on marina breakwaters facing the lagoon (Fig. 3d).

Comparison of whelk density at the site where they were the most abundant (Akhziv, incisioned-rock habitat) during October of 5 consecutive years (1995 to 1999) revealed a consistent trend of decrease in whelk abundance (mean \pm SD = $7.1 \pm 6.7,6.4 \pm 4.9,5.6 \pm 5.3,3.6 \pm 2.7,2.4 \pm$ 2.4 ind. $\mathrm{m}^{-2}$, respectively; $\mathrm{n}=10$; regression: $\left.\mathrm{r}^{2}=-0.96, F=79, \mathrm{p}=0.003\right)$. A significant 2-fold reduction in whelk numbers was recorded in the Bat-Yam infralittoral gully-wall habitat between August 1996 and August 1997 (2.5 \pm 2.7 and $1.3 \pm$ 2.3 ind. $\mathrm{m}^{-2}$, respectively; $\mathrm{n}=40, \mathrm{p}=0.03$ ).

Analysis of the whelks' spatial distribution in the midlittoral and infralittoral habitats, where they were relatively abundant $\left(>0.5\right.$ ind $\left.\mathrm{m}^{-2}\right)$, revealed patchiness at most sites (Morisita index, p $<0.05$, Table 3). The degree of aggregation varied from tightly grouped snails (up to a few $\mathrm{cm}$
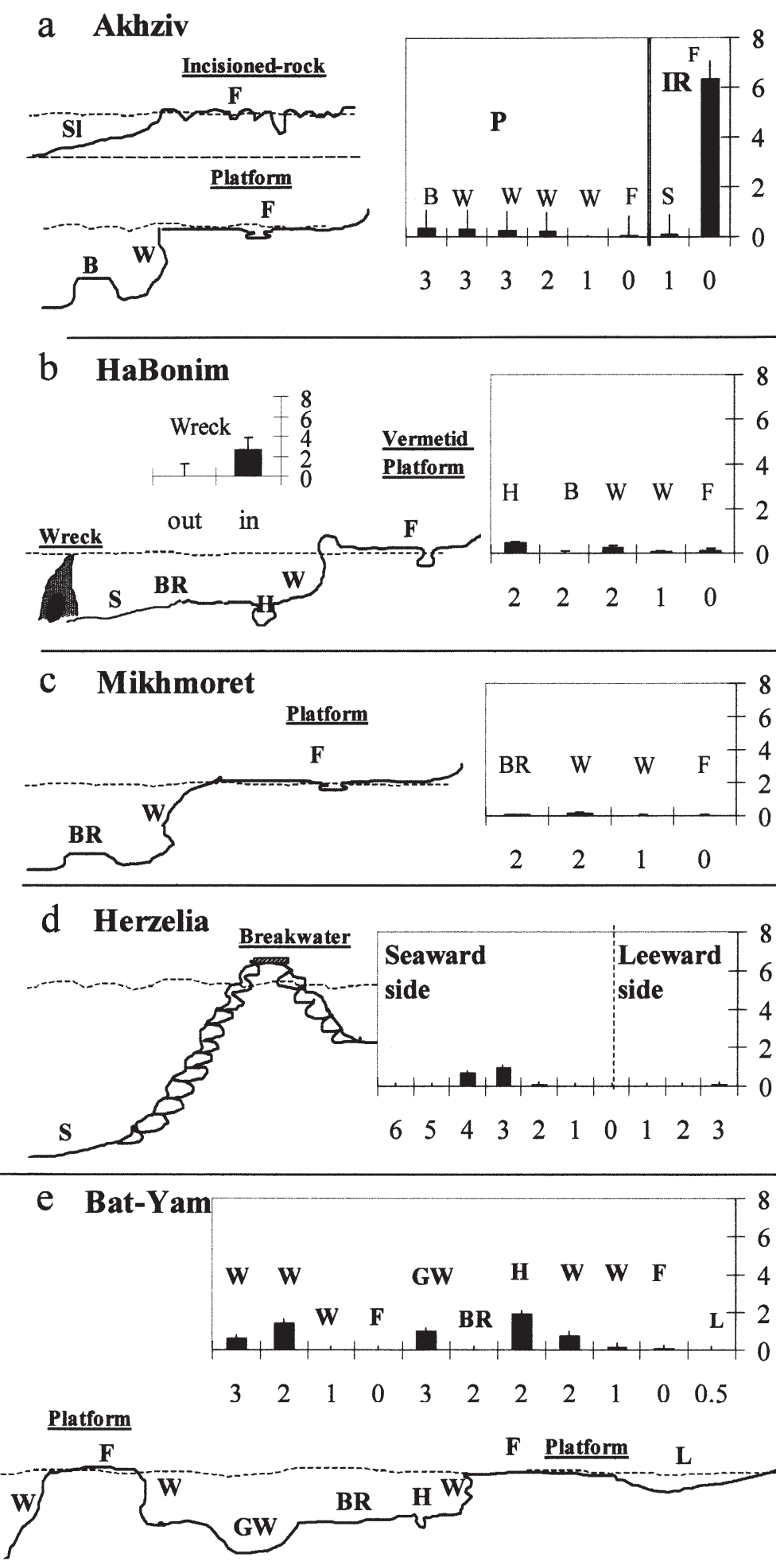

Fig. 3. Stramonita haemastoma. Mean $(+\mathrm{SE})$ density $\mathrm{m}^{-2}$ ( $y$-axis) in relation to depth (m, $x$-axis) and habitat type, calculated from censuses conducted between September and November 1996 at different mid and infralittoral sites and habitats along the Israeli coast. A schematic profile of each site is shown (not to scale). B: boulders; BR: bedrock; F: flat; GW: gully-wall; H: holes; IR: incisioned-rock; L: lagoon; P: platform; S: sand; Sl: rocky slope; W: platform wall 
Table 2. Number of holes and crevices per quadrat of $1 \times 1 \mathrm{~m}$ with an opening area $>100 \mathrm{~cm}^{2}$ in 2 types of midlittoral rocky habitats at Akhziv

\begin{tabular}{|lcc|}
\hline Habitat & No. $\mathrm{m}^{-2}$ & No. of quadrats \\
\hline Incisioned-rock A & $0.70 \pm 0.47$ & 10 \\
Incisioned-rock B & $0.77 \pm 0.46$ & 10 \\
Platform & $0.05 \pm 0.34$ & 60 \\
\hline
\end{tabular}

apart) in midlittoral or shallow infralittoral burrows and crevices to relatively loose aggregations (tens of $\mathrm{cm}$ apart) in other infralittoral rocky habitats. In the BatYam gully-walls, we recorded a change from a patchy distribution pattern in August, when the snails were observed near egg capsules, to a random pattern in October, the month this site was surveyed (Table 3).

\section{Whelk population size structure}

A preliminary survey conducted in the infralittoral at Akhziv during November 1994 revealed an unusually small variability in whelk size (average shell length $58.9 \pm 4.3 \mathrm{~mm}, \mathrm{n}=16$ ) and an absence of whelks $<50 \mathrm{~mm}$. A similar size structure was found to be the rule in all other sites explored by us (September and October 1996, January 1998), both in the mid- and infralittoral zones (Fig. 4). Whelks $<40 \mathrm{~mm}$ were extremely rare $(<0.5 \%, \mathrm{n}=3024)$, and the size range was remarkably skewed towards large snails. The population with the smallest mean size (ca $43 \mathrm{~mm}, \mathrm{p}<0.001$ ) was found in HaBonim, where the smallest individual measured (26 mm) in the present study was also found. A significant increase in mean shell length (up to $14 \%$ )

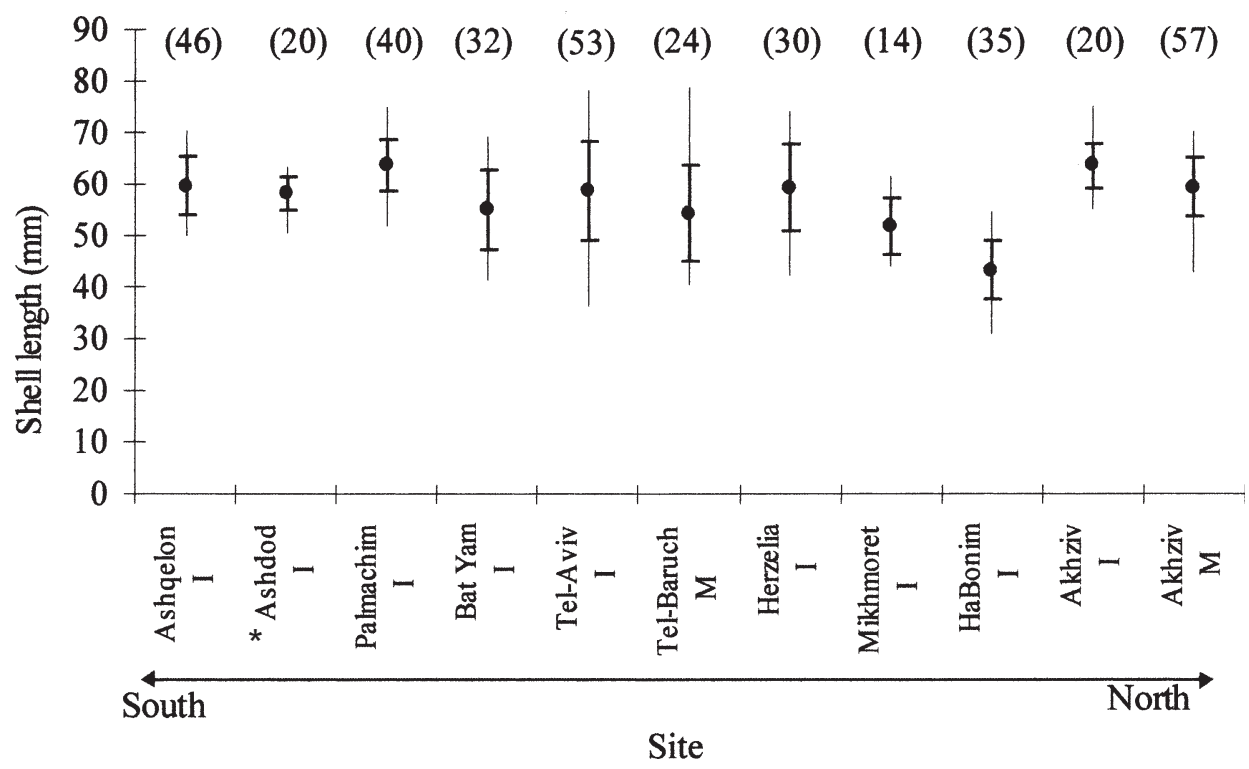

over a period of 2 to $5 \mathrm{yr}$ was found in Bat-Yam and Akhziv (Fig. 5). The increase in whelk size was negatively correlated with mean density $\left(\mathrm{r}^{2}=0.98, \mathrm{p}<0.001\right.$, Akhziv midlittoral).

In the infralittoral gully-wall habitat in Bat-Yam we observed considerable variations in whelk size range over a 1 yr period (Fig. 6). In April 1996, whelk size ranged from 50 to $75 \mathrm{~mm}$, while the presence of smaller individuals in August widened the size range to 35-75 $\mathrm{mm}$ (Fig. 6). During the entire study period such a wide size range was found only in Bat Yam. Mean whelk size in August was significantly lower than in April $(\mathrm{p}<0.001)$. By the following winter (December to February), whelk size range once again narrowed (49 to $65 \mathrm{~mm}$ ) and mean size increased (Fig. 6). In August 1997, whelks <50 mm were not found (Fig. 6). A much smaller but significant ( $p<0.001$ ) variation in whelk mean size (up to $4 \mathrm{~mm}$ ) was observed in a midlittoral incisioned-rock habitat in Akhziv (Fig. 7), where whelks $<50 \mathrm{~mm}$ were not found during the entire study period. A significant inverse relationship was found between whelk abundance in this site and mean whelk size $(r=-0.80, p<0.05)$. Intra-site comparison (Akhziv) of mean whelk size showed that snails in the infralittoral were significantly larger than their counterparts in the midlittoral (Table 4). Moreover, whelks found in infralittoral burrows surrounded by mussels were larger than those on walls covered by both barnacles and mussels (Bat-Yam: Table 4).

\section{Food availability}

The average density of the potential food items of the whelks varied by several orders of magnitude among
Fig. 4. Stramonita haemastoma. Mean \pm SD (heavy lines) and range (thin lines) of shell length at different sites and habitats (M: midlittoral; I: infralittoral) during September and October 1996 and January 1998 (*). Sample size in parentheses 
Table 3. Stramonita haemastoma. Morisita index of dispersion $\left(I_{\delta}\right)$ and significance level calculated for populations with densities $>0.5$ ind. $\mathrm{m}^{-2}$ in September and October or August (indicated by ${ }^{*}$ ). M: midlittoral; I: infralittoral; P: patchy; R: random. ns: not significant

\begin{tabular}{|c|c|c|c|c|c|c|c|}
\hline Location & Habitat type & Zone & Mean density (ind. $\mathrm{m}^{-2}$ ) & $I_{\delta}$ & $F_{0}$ & $\mathrm{p}$ & Pattern \\
\hline Akhziv & Incisioned-rock & M & 6.4 & 1.29 & 3.03 & $<0.05$ & $\mathrm{P}$ \\
\hline HaBonim & Shipwreck & $\mathrm{I}$ & 2.6 & 1.38 & 2.09 & ns & $\mathrm{R}$ \\
\hline Herzelia & Marina breaker & I & 0.92 & 2.42 & 2.29 & $<0.005$ & $\mathrm{P}$ \\
\hline Tel-Baruch & Beachrock & M & 0.67 & 2.68 & 2.1 & $<0.05$ & $\mathrm{P}$ \\
\hline Tel-Aviv & Breakwater & $\mathrm{I}$ & 0.85 & 1.85 & 1.72 & $<0.01$ & $\mathrm{P}$ \\
\hline Bat-Yam & Near-shore platform walls & I & 0.75 & 1.52 & 1.38 & ns & $\mathrm{R}$ \\
\hline Bat-Yam & Off-shore platform walls & I & 1.17 & 2.55 & 2.80 & $<0.001$ & $\mathrm{P}$ \\
\hline Bat-Yam & Gully-walls & I & 0.95 & 0.82 & 0.82 & ns & $\mathrm{R}$ \\
\hline Bat-Yam & Gully-walls* & I & 1.6 & 2.9 & 3.21 & $<0.005$ & $\mathrm{P}$ \\
\hline Bat-Yam & Nearshore bedrock & I & 1.85 & 4.62 & 7.86 & $<0.0001$ & $\mathrm{P}$ \\
\hline Ashqelon & Boulders & I & 0.6 & 6.09 & 4 & $<0.0001$ & $\mathrm{P}$ \\
\hline
\end{tabular}

locations and habitats (Fig. 8). Prey density (mostly mussels) was highest (ca 100 ind. per $100 \mathrm{~cm}^{2}$ ) in the incisioned-rock habitat and on platforms in Akhziv and on a platform in Bat-Yam. An order of magnitude lower prey density (mostly limpets and vermetids) was found on the incisioned-rocks in HaBonim; 2 orders of magnitude lower density was found on the platform in Mikhmoret (mostly vermetids and mussels); and 3 orders of magnitude lower density (mostly vermetids and mussels) was found on the HaBonim platform (Fig. 8a). Sand and perennial macroalgae such as Laurencia papillosa covered the surface of the latter habitat. The Red Sea emigrant mussel Brachidonthes pharaonis comprised almost $100 \%$ of the mussel beds on the Akhziv platforms, whereas in the incisionedrock habitat at the same site and on the platform at Bat-Yam, individuals of the smaller indigenous mussel Mytilaster minimus were abundant among the larger B. pharaonis. Large individuals of B. pharaonis (>20 mm) comprised ca $15 \%$ (ca 40 ind.) of the total number of mussels in an area of $100 \mathrm{~cm}^{2}$ on platforms within the mussel bed.

Fig. 5. Stramonita haemastoma. Comparison of (mean + SE) shell length of populations over 2 to 5 successive years in the infralittoral at Bat-Yam and infralittoral and midlittoral habitats at Akhziv. Values for dates connected by a line are not significantly different (1-way ANOVA)

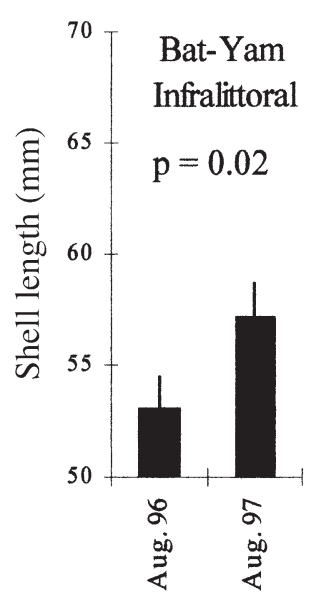

Prey density in the infralittoral was at least an order of magnitude lower than that recorded in most midlittoral habitats (Fig. 8b). Barnacles were the most prevalent organisms on walls and boulders in the infralittoral of Akhziv and HaBonim sites (ca 5 to 20 ind. per $100 \mathrm{~cm}^{2}$ : Fig. 8b), while mussels (ca 10 ind. per $100 \mathrm{~cm}^{2}$, mostly patches of Brachidonthes pharaonis) and barnacles were prevalent in Bat-Yam. In Akhziv and Bat-Yam, most barnacles were bigger (ca 8-fold by orifice length), and mussel density was greater than at HaBonim, a site which was densely covered by macroalgae. Likewise, low prey density (<0.5 ind. per $100 \mathrm{~cm}^{2}$ : Fig. 8b) was found on infralittoral bedrock surfaces which were covered by macroalgae such as Jania rubens or Coralina elongata and by 2 to $25 \mathrm{~mm}$ of sediment.

\section{DISCUSSION}

\section{Whelk population features}

Our study confirms that the whelk Stramonita haemastoma is present only in small numbers along
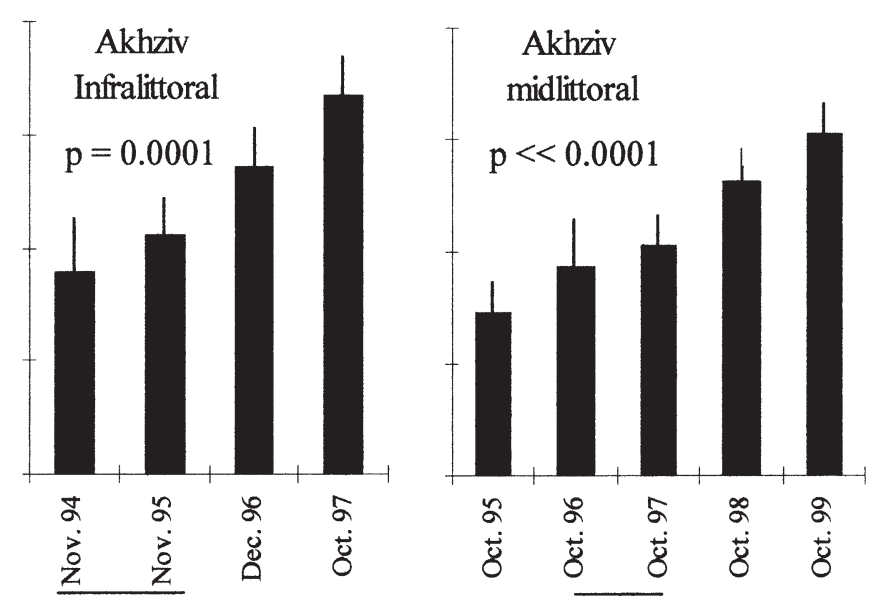

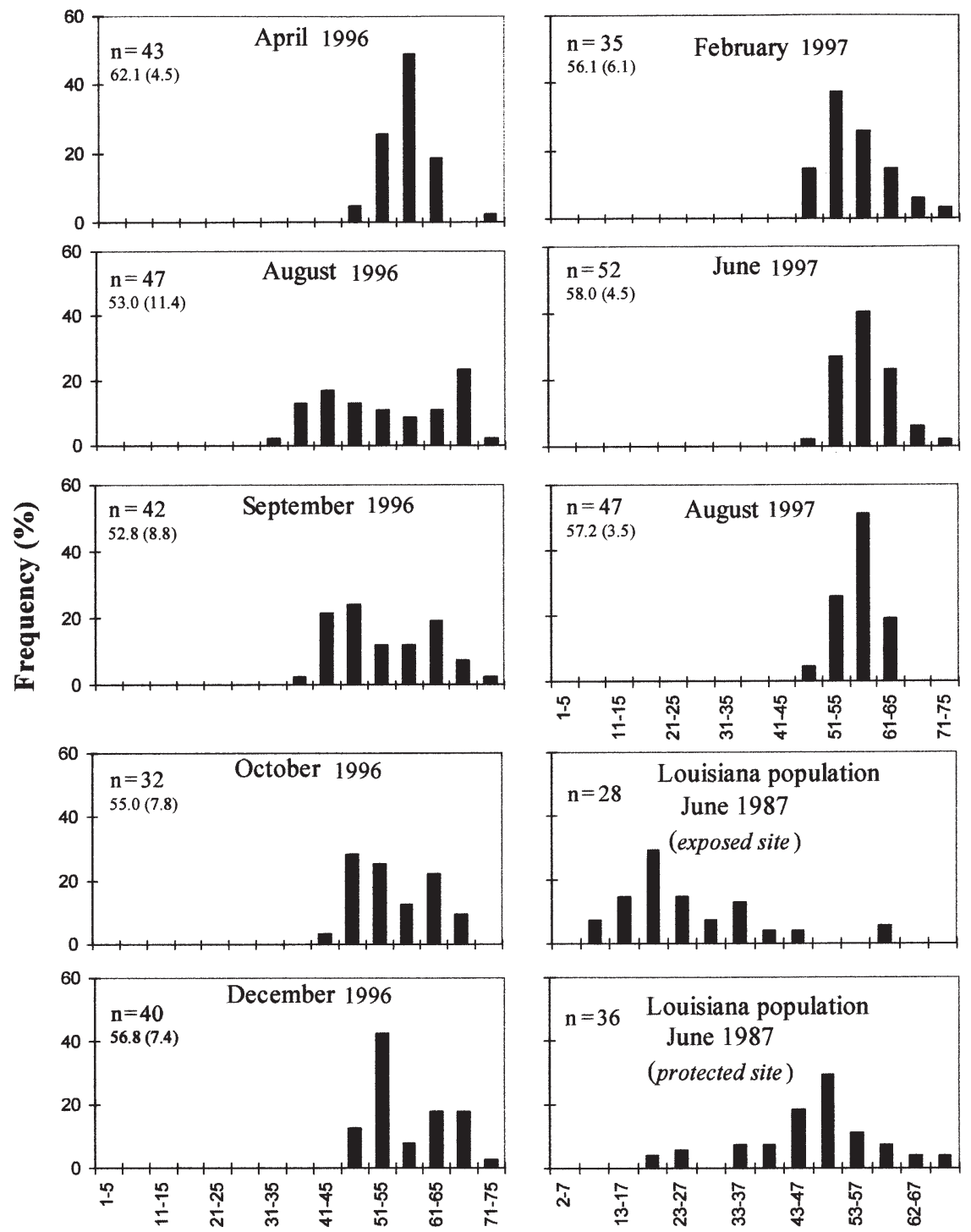

Size class (mm)

Fig. 6. Stramonita haemastoma. Size-frequency distribution of whelks on the infralittoral gully-wall habitat of Bat-Yam, and of S. haemastoma floridana from the Louisiana coast (modified from Richardson \& Brown 1990). Mean length ( \pm SD in parentheses) of the Israeli population are shown at top left of each graph the Israeli coast. A maximum density of 12 to 16 ind. $\mathrm{m}^{-2}$ was found only in 3 out of the 1364 quadrats counted in autumn 1996. A mean of 6.5 ind. $\mathrm{m}^{-2}$ was recorded only in the incisioned-rock midlittoral habitat at Akhziv (Fig. 3). In most other sites and habitats, densities were 1 or 2 orders of magnitude lower. In comparison, S. haemastoma on the Louisiana oyster reefs attain densities of ca 38 ind. $\mathrm{m}^{-2}$ (Brown \& Richardson 1987), and in other parts of the world they may reach densities of hundreds and sometime more than 1000 ind. $\mathrm{m}^{-2}$ (e.g., Venezuela: see review by Butler 1985). Most other whelk species studied in midlittoral rocky habitats can also attain densities of tens to hundreds of ind. $\mathrm{m}^{-2}$ (e.g., Menge 1978, Sousa 1984, Jernakoff \& Fairweather 1985, Dye et al. 1991, Carroll \& Highsmith 1996). Surprisingly, $S$. haemastoma, which is abundant in midlittoral and infralittoral habitants in Louisiana (Butler 1985, Brown \& Richardson 1987), is rare on platforms of sandstone or limestone in the midlittoral zone along the Israeli coast. As shown in the present study, along the Israeli coat $S$. haemastoma is relatively more abundant in lowermidlittoral habitats of the incisionedrock type, which provide ample shelter (holes, crevices) as well as food (mostly mussels), and in shallow (2 to $4 \mathrm{~m}$ ) infralittoral habitats.

Our results (Figs 8 \& 9) indicate that food availability is a poor predictor of whelk density, especially in the midlittoral, and cannot be currently con-

Table 4. Stramonita haemastoma. Comparison of mean $( \pm \mathrm{SD})$ shell length of populations in Akhziv and Bat Yam in similar or different rocky habitats. $F$ critical $=3.98,1$-way ANOVA, n varied between 71 and 94

\begin{tabular}{|c|c|c|c|c|c|c|c|}
\hline \multirow[t]{2}{*}{ Site } & \multirow{2}{*}{ Date } & \multicolumn{2}{|c|}{ Midlittoral } & \multicolumn{2}{|c|}{ Infralittoral } & \multicolumn{2}{|c|}{ Significance } \\
\hline & & $\begin{array}{l}\text { Incisioned } \\
\text { rocks a }\end{array}$ & $\begin{array}{l}\text { Incisioned } \\
\text { rocks b }\end{array}$ & $\begin{array}{l}\text { Bedrock } \\
\text { burrows }\end{array}$ & $\begin{array}{l}\text { Boulders/ } \\
\text { gully-walls }\end{array}$ & F & $\mathrm{p}$ \\
\hline \multirow[t]{4}{*}{ Akhziv } & Mar 1997 & $60.9 \pm 4.8$ & $63.0 \pm 5.7$ & & & 2.59 & 0.11 \\
\hline & Oct 1997 & $60.1 \pm 3.6$ & $61.3 \pm 5.5$ & & & 1.21 & 0.2 \\
\hline & Oct 1995 & $57.2 \pm 3.8$ & & & $62.2 \pm 4.5$ & 30.9 & $<0.001$ \\
\hline & Jun 1997 & $62.1 \pm 3.1$ & & & $66.3 \pm 4.3$ & 11.4 & 0.001 \\
\hline \multirow[t]{3}{*}{ Bat-Yam } & Feb 1997 & & & $63.5 \pm 5.7$ & $56.1 \pm 6.1$ & 24.8 & $<0.001$ \\
\hline & Jun 1997 & & & $62.6 \pm 4.9$ & $58.0 \pm 4.5$ & 23.9 & $<0.001$ \\
\hline & Aug 1997 & & & $61.7 \pm 4.3$ & $57.2 \pm 3.5$ & 24.5 & $<0.001$ \\
\hline
\end{tabular}




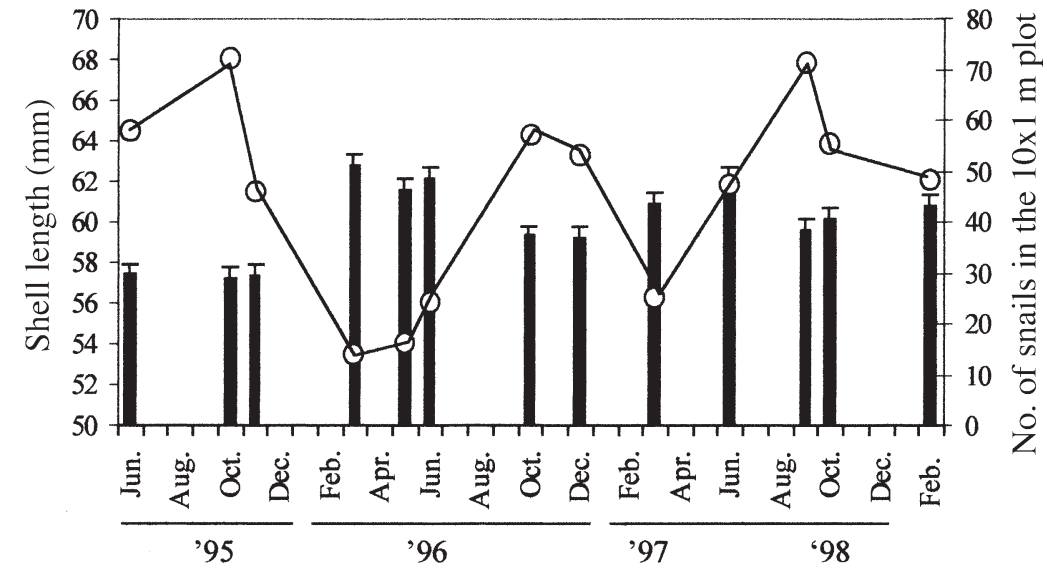

Fig. 7. Stramonita haemastoma. Average (+SE) shell length (bars) and density (O) in a fixed $1 \times 10 \mathrm{~m}$ midlittoral plot located in an incisioned-rock habitat in Akhziv

sidered a limiting factor to whelk numbers in most midlittoral rocky habitats along the Israeli coast. Mussels, for example, a preferred prey of Stramonita haemastoma (Brown \& Richardson 1987), are abundant on platforms where whelks are rare. At present, the dominant mussel is Brachidonthes pharaonis, a Lessepsian migrant, which was rare 20 yr ago (Safriel \& Sasson-Frosting 1988) but now forms dense beds in many locations, mostly in the midlittoral zone. $B$. pharaonis is 3 times larger than the indigenous species Mytilaster minimus and is also larger than the local barnacles. Hence, where large individuals of $B$. pharaonis are found, the whelk's food biomass is expected to be higher than in areas occupied by other potential food items. Moreover, due to its large size, this mussel is more susceptible to predation by whelks. Preliminary laboratory experiments show that $B$. pharaonis is a food item preferred by $S$. haemastoma over the indigenous mussel and barnacles (Rilov et al. 1996). We cannot exclude the effect of food limitation on whelk density in certain habitats. For example, in infralittoral habitats at depths of 3 to $4 \mathrm{~m}$ on bedrock where food was scarce (Fig. 8), whelks were also rare (Fig. 3), whereas on vertical surfaces at the same depth where food was more abundant, whelks were also more abundant (Figs $2 \& 8$ ).
Factors other than food availability, particularly physical conditions such as wave action or desiccation, may influence whelk abundance (e.g., Moran 1985, Menge et al. 1994). The Israeli coastline is straight (Fig. 1) and without protected rocky areas, and thus most rocky habitats are directly exposed to the prevailing westerly winds. This, together with minor tidal amplitudes (rarely exceeding $30 \mathrm{~cm}$ ) that are usually overridden by water motion (Safriel 1966), result in high and almost constant exposure of the platforms to strong wave action. Maximum wave height $>0.5 \mathrm{~m}$ occurs $80 \%$ of the time. Consequently, even during low tides, the lower midlittoral rocks are exposed to wave action. In addition, when stranded organisms including whelks occasionally die stressful desiccation conditions develop, mostly in spring and autumn, when easterly hot winds, which prevail together with high barometric pressure for several days, dry out the platforms (Rilov 1999). Expo-

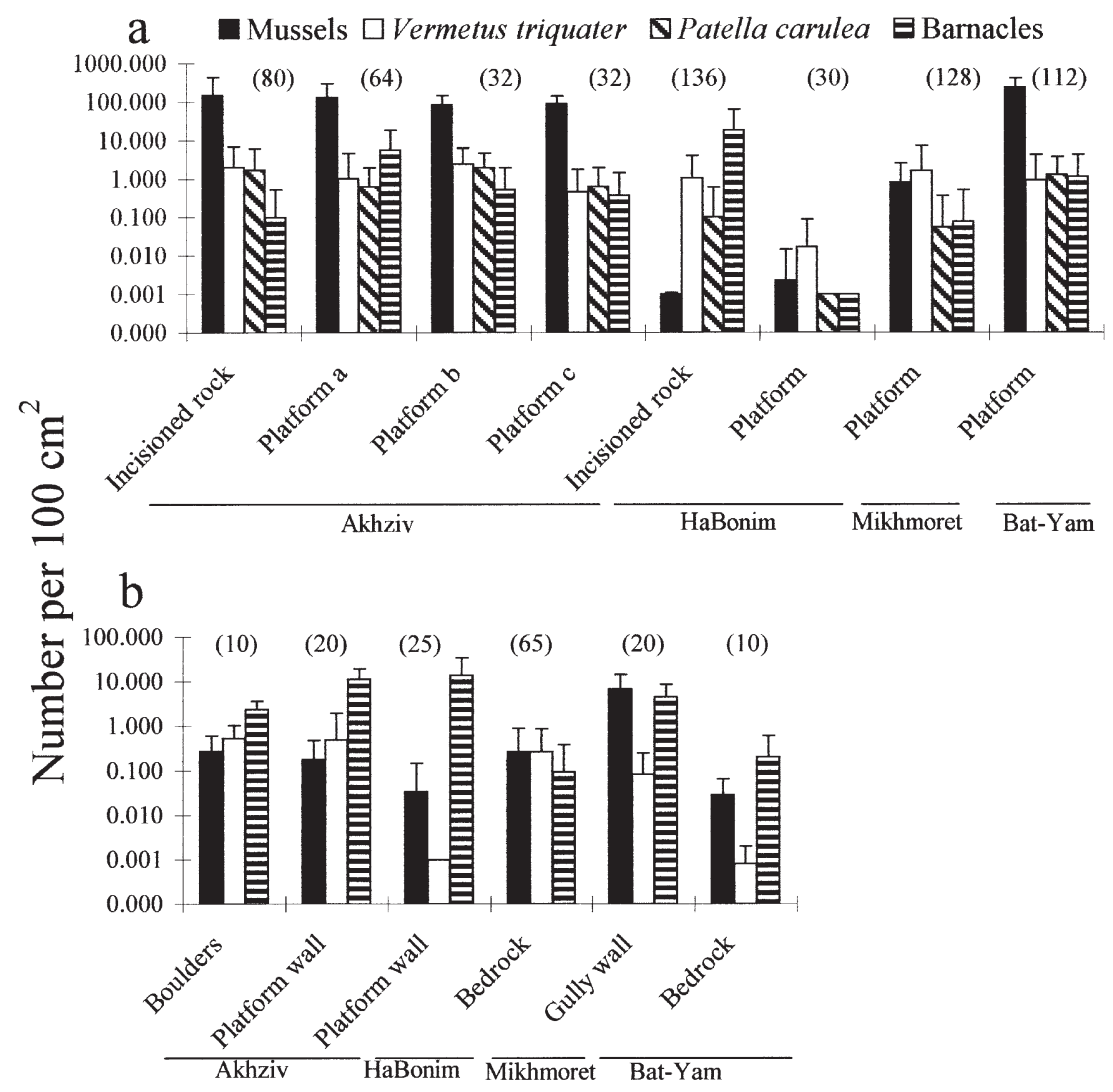

Fig. 8. Mean $(+\mathrm{SD})$ densities (log scale) of potential prey groups in the (a) low midlittoral zone and (b) infralittoral zone at a northern site (Akhziv) and 3 central locations (HaBonim, Mikhmoret and Bat-Yam). Sample size in parentheses 


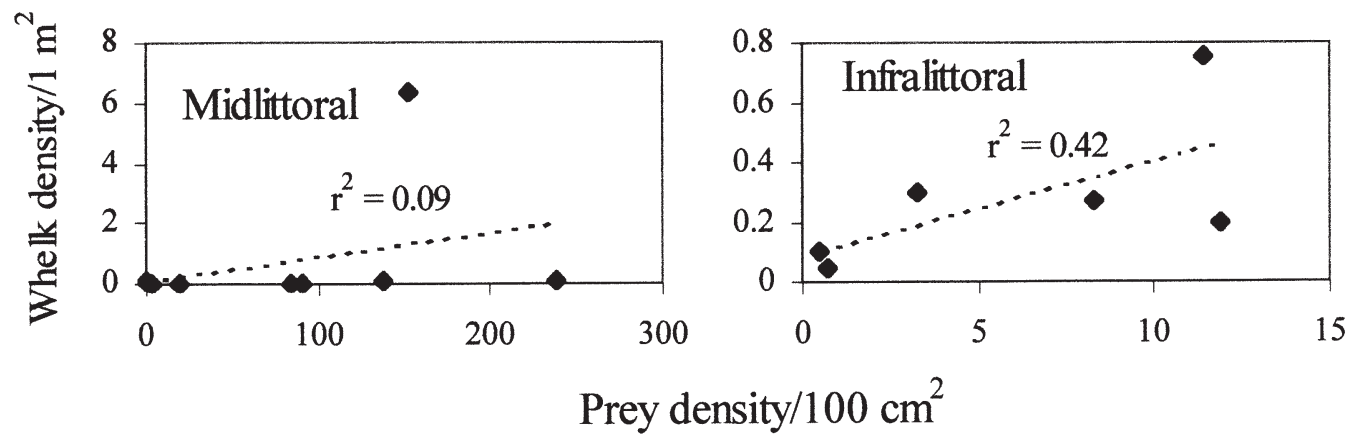

Fig. 9. Stramonita haemastoma. Relationship between whelk density and prey density in mid- and infralittoral habitats

sure to waves increases the risk of dislodgment for whelks (Menge 1978, 1991, 1994, Burrows \& Hughes 1989, Richardson \& Brown 1990). Furthermore, in response to desiccation, whelks tend to aggregate in shelters (Moran 1985). We suggest that in midlittoral habitats along the Israeli coast unfavorable foraging conditions caused by the scarcity of shelters (lower structural complexity), together with an increased risk of dislodgment due to high wave action, or the impact of desiccation at other times, restrict the presence of the whelks on platform flats but not in incisioned-rock habitats. Wave action may also explain whelk scarcity in most shallow ( 1 to $2 \mathrm{~m}$ ) infralittoral habitats, where food availability is relatively high. In the few exceptions when relatively large numbers of whelks were found in the shallow infralittoral, they were all in sheltered habitats (burrows, or inside a shipwreck). The higher numbers of whelk on boulders and walls in deeper infralittoral rocky habitats (at 3 to $4 \mathrm{~m}$ depth: Fig. 2) may be attributed to the lack of strong turbulence and thus a diminished risk of dislodgment.

Stramonita haemastoma exhibits a patchy distribution in most habitats (Table 3 ). When foraging on large food items such as oysters, $S$. haemastoma forms aggregations, and therefore achieves a higher feeding efficiency (Brown \& Alexander 1994). Along the Israeli coast $S$. haemastoma does not exhibit feeding aggregations, possibly because of the small size of the available prey. Whelk aggregations are usually of nonfeeding individuals taking shelter in wave-swept habitats in the midlittoral and shallow infralittoral. Grouping of S. haemastoma does occur during capsule deposition.

A most striking finding in our study was that the present populations of Stramonita haemastoma along the Israeli coast consist almost exclusively of large individuals $(>35 \mathrm{~mm}$ ), with a mean size (between 55 and $65 \mathrm{~mm}$ ) smaller than the maximum size by only 11 to $21 \mathrm{~mm}$. This population structure indicates a lack of recruitment of juveniles at least in the past 2 to $3 \mathrm{yr}$. A different population structure is reported from the Louisiana coast, where the populations of $S$. haemastoma are composed of individuals within the size range
7 to $72 \mathrm{~mm}$ (Fig. 6), and juveniles regularly appear in summer (Brown \& Richardson 1987, Richardson \& Brown 1990). In the Azores, mostly small snails 5 to $40 \mathrm{~mm}$ are found (Spence et al. 1990).

Between-site variability of Stramonita haemastoma size structure along the Israeli coast is small. Two sites stand out: the Bat-Yam site, where one recruitment episode was once recorded (Fig. 6), and the HaBonim site, where the population of $S$. haemastoma is composed of smaller individuals (mean size $25 \%$ smaller than elsewhere) and large snails are missing. It has been suggested that wave action affects the growth rate and size of intertidal snails. Increased metabolic rates in S. haemastoma floridana (Richardson \& Brown 1990) and limited time available for feeding in 2 limpets and a whelk (Brown \& Quinn 1988) were suggested to decrease the amount of energy available for growth in wave-swept areas, thereby limiting their size. Since the Israeli coast is straight and without sheltered rocky areas, exposure along the shore is uniform. Thus, it is less likely that wave disturbance alone can account for reduced growth rate and smaller size whelks at a single site. Alternatively, we suggest that low food biomass and limited prey availability (smaller sized barnacles and low mussel density: Fig. 8) recorded at HaBonim could locally reduce the growth rate of the whelks. Between-habitat variability in whelk size is evident along the Israeli coast. Infralittoral whelks are often larger than those in the midlittoral at the same site, despite smaller available prey (mostly barnacles) in the former. Wave action, in this case, may account for the difference. The data suggest a higher growth rate in the infralittoral which may be attributable to more efficient feeding, facilitated by less wave disturbance. Desiccation is less likely to contribute to the difference in whelk size because it occurs only periodically (in spring and autumn) and for periods of only a few days.

\section{Juvenile rarity}

We present here 4 possible explanations for the observed rarity of small Stramonita haemastoma 
$(<50 \mathrm{~mm})$ during our $5 \mathrm{yr}$ study. The first assesses the possibility of methodological problems that might have prevented us from noticing small individuals, the others address environmental factors relevant to the eastern Mediterranean that could have left their impact on the whelk population structure in recent years.

\section{Methodological problems}

There is a small likelihood that young individuals of Stramonita haemastoma are in fact present along the Israeli coast but totally escaped our 5 yr thorough investigation of rocky habitats and bordering sandy sites. If this is the case, then along the Israeli coast, unlike other places, the small whelks may indeed inhabit non-rocky habitats or rocky habitats inaccessible to divers. However, this explanation contradicts observations made 20 to $30 \mathrm{yr}$ ago in which small individuals of $S$. haemastoma were seen along the Israeli coast (L. Fishelson pers. comm.). Extremely rapid growth in the first year of life could be argued as another possible reason for the observed paucity of juveniles. Butler (1985) showed that under laboratory conditions with an abundance of food, some of the 600 sampled individuals of $S$. haemastoma grew rapidly and attained a size of $55 \mathrm{~mm}$ within a period of only 6 mo and were larger than others known to be yr old. Along the Israeli coast, conditions seem to be far less favorable (high wave action and relatively small size prey), and therefore, slower growth rates would be expected. Moreover, we observed egg capsules of $S$. haemastoma during August and early September, thus whelks $<35 \mathrm{~mm}$ should have been observed during spring or summer. This is based on an embryonic stage that lasts for about $2 \mathrm{wk}$ (D'Asaro 1966, Roller \& Stickle 1989) and a planktonic veliger stage that lasts no less than 2 mo (Butler 1985, Dobberteen \& Pechenik 1987). Indeed, during the 5 yr study, we only observed individuals of this size in August and September 1996 (Bat-Yam: Fig. 6). This finding suggests a successful recruitment event at this site and supports the conclusion that the absence of small individuals in other cases is real. It also suggests that recruitment events may occur sporadically and locally. Recruitment in $S$. haemastoma may be erratic (Brown \& Richardson 1987); nevertheless, it is unlikely that such low recruitment over a period of at least $5 \mathrm{yr}$ (half of the maximum life span of the species) is a normal phenomenon along the Israeli coast. The absence or rarity of juveniles of $S$. haemastoma along the Israeli coast implies the failure or a serious decline in recruitment of young whelks. The low abundance of the whelks and the consistent increase in average whelk size over the study period (Fig. 5) also suggest aging of the whelk populations.
The exact cause of such a dramatic change in the population structure is yet unknown..

\section{Changes in salinity}

We suggest that recent changes in salinity range may have reduced larval or juvenile survival. The western Atlantic subspecies Stramonita haemastoma floridana has been shown to prefer a salinity level of $25 \%$ (Garton \& Stickle 1980, Stickle 1985). Gunter (1979) reported the presence of $S$. haemastoma floridana in estuaries where salinities vary between 15 and $35 \%$. In some locations, S. haemastoma floridana is even found in salinities as high as $42 \%$ (W. B. Stickle pers. comm.). However, Roller \& Stickle (1989) demonstrated that the embryonic intracapsular developmental stages of $S$. haemastoma are less euryhaline than the adults: survival is significantly lower at 30 and $35 \%$ compared with 20 and $25 \%$. Thus, it is possible that the relatively high salinity in the eastern Mediterranean limits the establishment of large whelk populations. Prior to the construction of the Aswan Dam (Egypt) in 1964, the undisturbed inflow of the Nile into the Mediterranean caused seasonal fluctuations in salinity. The floodwater reached the coast of Israel during the first half of September each year and the salinity declined from 39\%o to as low as 31.8\% (Hecht 1964). After the construction of the dam, these salinity fluctuations diminished (Sharaf El Din 1977). It is therefore proposed that the current lack of significant seasonal inflow from the Nile into the Mediterranean with the resultant decrease in seasonal changes in salinity and possibly other flood-related effects (e.g., nutrient input, productivity) at the time of the whelks' breeding season could have reduced the reproductive output and juvenile survival of $S$. haemastoma along the Israeli coast.

\section{TBT pollution}

The biocide tributyltin (TBT), which leaches from antifouling paints, is a pollutant known to affect whelk populations, causing female sterility at extremely low concentrations (Bryan \& Gibbs 1986). This phenomenon, termed 'imposex' (Smith 1980), can cause the extinction of whelks in highly TBT-polluted areas (reviewed by Gibbs \& Bryan 1996). Imposex has been described in Stramonita haemastoma, although the absence of juveniles was not reported (Spence et al. 1990). In recent years, the number of marinas and boating activity have markedly increased along the Israeli coast. In a recent study we described imposex and TBT contamination in populations of $S$. haemas- 
toma along the coast of Israel (Rilov et al. 2000). TBT levels were extremely high near pollution sources (>400 $\mathrm{ng} \mathrm{g}^{-1}$ ) and relatively high TBT levels (compared to levels in areas where TBT is regulated: Douglas et al. 1993) were also found in sites remote from boating activity (Akhziv and HaBonim). We suggest that TBT pollution lowers the reproduction success at highly polluted sites and consequently contributes to lower recruitment and overall lower abundance of this whelk in the region.

\section{Predation by an invasive species}

An Indo-Pacific medusa, Rhopilema nomadica, has invaded the eastern Mediterranean, and since 1989 appears annually in enormous numbers along the Israeli coast from July to October (Lotan et al. 1994). Medusae and ctenophores have been shown to substantially reduce the numbers of planktonic organisms such as fish larvae (Moller 1984, Purcell et al. 1993, Carlton 1996) and zooplankton (Schneider \& Behrends 1994, Olesen 1995). Stramonita haemastoma has a pelagic larva (Spight 1977), which is assumed to spend a few months in the plankton at the time of the medusa bloom. It is thus possible that the large populations of invading $R$. nomadica in recent years have increased veliger mortality and reduced whelk recruitment. We do not exclude the possibility that other predators can also affect the abundance of young whelks by preying on the benthic stages (i.e., eggs and juveniles). However, it is quite unlikely that predation alone would eliminate juveniles from the population. Butler (1985), who studied the whelk's populations in the western Atlantic, stated that $S$. haemastoma 'has no documented natural predators in the adult stage'. We found no evidence along the Israeli shore to contradict Butler's conclusion.

Finally, recruitment failure of Stramonita haemastoma may result from an additive or a synergistic effect of salinity changes, TBT pollution, and massive larval predation by a novel predator. The possible effect of these, together with other stressors such as diseases (Altstatt et al. 1996) should be further investigated. The decline of the populations of $S$. haemastoma is expected to be relatively slow because of the relatively long life span of the whelk (up to $10 \mathrm{yr}$ : Butler 1985). However, if the trend of population decline continues, this species may become locally extinct. The ecological consequences of the dwindling whelk populations are presently being investigated.

Acknowledgements. We thank W. B. Stickle for reviewing an early version of this manuscript and for providing constructive comments. We thank the Israeli Meteorological Service for supplying the raw data on wave height. Special thanks to the Nature Reserves Authority for allowing us to work in the nature reserves and for partial financial support. N. Paz is acknowledged for editorial assistance. We also thank the Akhziv Field School for accommodating us.

\section{LITERATURE CITED}

Altstatt JM, Ambrose RF, Engle JM, Haaker PL, Laffferty KD, Raimondi PT (1996) Recent declines of black abalone Haliotis cracherdii on the mainland coast of central California. Mar Ecol Prog Ser 142:185-192

Barash A, Danin Z (1992) Fauna Palestina. Mollusca I. Annotated list of Mediterranean molluscs of Israel and Sinai. Keter Press Enterprises, Jerusalem

Brown KM (1997) Size specific aspects of the foraging ecology of the southern oyster drill Stramonita haemastoma (Kool 1987). J Exp Mar Biol Ecol 214:249-262

Brown KM, Alexander JE Jr (1994) Group foraging in a marine gastropod predator: benefits and costs to individuals. Mar Ecol Prog Ser 112:97-105

Brown KM, Quinn JF (1988) The effect of wave action on growth in three species of intertidal gastopods. Oecologia 75:420-425

Brown KM, Richardson TD (1987) Foraging ecology of the southern oyster drill Thais haemastoma (Grey): constraints on prey choice. J Exp Mar Biol Ecol 114:123-141

Bryan GW, Gibbs PE, Huggett RJ, Hummerstone LG, Burt GR (1986) The decline of the gastropd Nucella lapillus around south-west England: evidence for the effect of tributyltin form antifouling paints. J Mar Biol Assoc UK 66:611-640

Burrows MT, Hughes RN (1989) Natural foraging of dogwhelk, Nucella lapillus (Linnaeus): the weather and whether to feed. J Molluscan Stud 55:285-295

Burrows MT, Hughes RN (1991) Variation in foraging behavior among individuals and populations of dogwhelks, Nucella lapillus: natural constrains on energy intake. J Anim Behav 41:161-170

Butler PA (1985) Synoptic review of the literature on the southern oyster drill Thais haemastoma floridana. NOAA Tech Rep NMFS 35:1-9

Carlton JT (1996) Marine bioinvasions: the alteration of marine ecosystems by nonindigenous species. Oceanography 9:36-43

Carroll ML, Highsmith RC (1996) Role of catastrophic disturbance in mediating Nucella-Mytilus interactions in the Alaskan rocky intertidal. Mar Ecol Prog Ser 138:125-133

D'Asaro CN (1966) The egg capsules, embryogenesis, and early organogenesis of a common oyster predator, Thais haemastoma floridana (Gastropoda: Prosobranchia). Bull Mar Sci 16:884-914

Dobberteen RA, Pechenik JA (1987) Comparison of larval bioenergetics of two marine gastropods with widely differing length of planktonic life, Thais haemastoma canaliculata (Gray) and Crepidula fornicata (L.). J Exp Mar Biol Ecol 109:173-191

Douglas EW, Evans SM, Frid CLJ, Hawkins ST, Mercer TS, Scott CL (1993) Assessment of imposex in the dogwhelk Nucella lapillus (L.) and tributyltin along the northeast coast of England. Invertebr Reprod Dev 23:243-248

Dye AH (1991) Feed prederences of Nucella crassilabrum and juvenile Concholepas concholepas (Gastropoda, Muricidae) from a rocky shore in southern Chile. J Molluscan Stud 57:301-307

Garton DW, Stickle WB (1980) Effects of salinity and temper- 
ature on the predation rate of Thais haemastoma on Crassostrea virginica spat. Biol Bull 158:49-57

Gibbs PE, Bryan GW (1996) TBT-induced imposex in neogastropd snails: masculinization to mass extinction. In: de Mora SJ (ed) Tributyltin: case study of an environmental contaminant, Cambridge University Press, Cambridge, p 212-236

Gosselin LA, Fu-Shiang C (1994) Feeding habits of newly hatched juveniles of an intertidal predatory gastropod, Nucella emarginata (Deshayes). J Exp Mar Biol Ecol 176: $1-13$

Goldman N (1995) Evaluation of chlorophyll A concentration at the north-east Mediterranean by using coastal zone color scanner-(CZCS). MSc thesis, Ben-Gurion University (in Hebrew)

Gunter G (1979) Studies of the southern oyster drill, Thais haemastoma. Gulf Res Rep 6:249-260

Hecht A (1964) On the turbulent diffusion of the water of the Nile floods in the Mediterranean Sea. State of Israel Prime Minister's Office, Natural Council of Research and Development, Bull 36:1-24

Jernakoff P, Fairweather PG (1985) An experimental analysis of interactions among several intertidal organisms. J Exp Mar Biol Ecol 94:71-88

Little C, Kitching JA (1996) The biology of rocky shores. Oxford University Press, Oxford

Liu L (1990) Genotypic and phenotypic adaptations of the southern oyster drills, Stramonita canaliculata and $S$. haemastoma floridana to salinity. $\mathrm{PhD}$ dissertation, Louisiana State University, Baton Rouge

Lotan A, Fine M, Ben-Hillel R (1994) Synchronization of the life cycle and dispersal pattern of the tropical invader scyphomedusan Rhopilema nomadica is temperature dependent. Mar Ecol Prog Ser 109:59-65

Menge BA (1978) Predation intensity in a rocky intertidal community. Relation between predator foraging activity and environmental harshness. Oecologia (Berl) 34:1-16

Menge BA (1991) Generalizing from experiments: is predation strong or weak in the New England (USA) rocky intertidal? Oecologia (Berl) 8/8:1-8

Menge BA, Lubchenco J (1981) Community organization in temperate and tropical rocky intertidal habitats: prey refuges in relation to consumer gradients. Ecol Monogr 51: $429-450$

Menge BA, Berlow EL, Blanchette CA, Navarrete SA, Yamada SB (1994) The keystone species concept: variation in interaction strength in a rocky intertidal habitat. Ecol Monogr 64:249-286

Menge BA, Daley BA, Wheeler PA, Dahlhoff E, Sanford E, Strub PT (1997) Benthic-pelagic links and rocky intertidal communities: bottom-up effects on top-down control? Proc Natl Acad Sci USA 94:14530-14537

Moller H (1984) Reduction of larval herring population by jellyfish predator. Science 224:621-622

Moran MJ (1985) The timing and significance of sheltering and foraging behavior of the predatory intertidal gastropod Morula marginalba blainville (Muricidae). J Exp Mar Biol Ecol 93:103-114

Morisita M (1959) Measuring of the dispersion on individuals and analysis of the distributional patterns. Mem Fac Sci Kyushu Univ Ser E Biol 2:215-234

Navarrete SA (1996) Variable predation: effects of whelks on a mid-intertidal successional community. Ecol Monogr 66: 301-321

Olesen NJ (1995) Clearance potential of jellyfish Aurelia aurita, and predation impact on zooplankton in a shallow cove. Mar Ecol Prog Ser 124:63-72
Paine RT (1994) Marine rocky shores and community ecology: an experimentalist's perspective. In: Kinne O (ed) Excellence in ecology, Vol 4. Ecology Institute, Oldendorf/Luhe

Por FD (1978) Lessepsian migration The influx of Red Sea biota into the Mediterranean by way of the Suez Canal. Springer-Verlag, Berlin

Purcell JE, Nemazie DA, Dorsey SE, Houde ED, Gamble JC (1993) Predation mortality of bay anchovy Anchoa mitchilli eggs and larvae due to scyphomedusae and ctenophores in Chesapeake Bay. Mar Ecol Prog Ser 114:48-58

Richardson TD, Brown KM (1990) Wave exposure and prey size selection in an intertidal predator. J Exp Mar Biol Ecol 142:105-120

Rilov G (1999) The whelk Stramonita haemastoma in the Eastern Mediterranean rocky littoral: biotic and abiotic perspectives. $\mathrm{PhD}$ dissertation, Tel-Aviv University

Rilov G, Gasith A, Benayahu Y (1996) Selected aspects in the ecology of large predatory gastropods in rocky littoral habitats along the Israeli Mediterranean coast. In: Steinberger Y (ed) Preservation of our world in the wake of change. Israel Society of Ecology and Environmental Quality Sciences (ISEEQS), Jerusalem, Pub VI B, p 608-613

Rilov G, Gasith A, Evans SM, Benayahu Y (2000) Unregulated use of TBT-based anti-fouling paints in Israel (eastern Mediterranean): high contamination and imposex levels in two marine gastropods. Mar Ecol Prog Ser 192: $229-238$

Robarts RD, Zohary T, Waiser MJ, Yacobi YZ (1996) Bacterial abundance, biomass, and production in relation to phytoplankton biomass in the Levantine Basin of the southeastern Mediterranean Sea. Mar Ecol Prog Ser 137: 273-281

Roller RA, Stickle WB (1988) Intracapsular development of Thais haemastoma canaliculata (Gray) (Prosobranchia: Muricidae) under laboratory conditions. Am Malacol Bull 6:189-197

Roller RA, Stickle WB (1989) Temperature and salinity effects on the intracapsular development, metabolic rates, and survival to hatching of Thais haemastoma canaliculata (Gray) (Prosobranchia: Muricidae) under laboratory conditions. J Exp Mar Biol Ecol 125:235-251

Safriel UN (1966) Recent vermetid formation on the Mediterranean shore of Israel. Proc Malacol Soc Lond 37:27-33

Safriel UN (1974) Vermetid gastropods and intertidal reefs in Israel and Bermuda. Science 186:1113-1115

Safriel UN, Sasson-Frosting Z (1988) Can colonizing mussel outcompete indigenous mussel? J Exp Mar Biol Ecol 117: 211-226

Safriel UN, Gilboa A, Felsenburg T (1980) Distribution of rocky intertidal mussels in the Red Sea coasts of Sinai, the Suez Canal, and the Mediterranean coast of Israel, with special reference to recent colonizer. J Biogeogr 7: 39-62

Schneider G, Behrends G (1994) Population dynamics and the trophic role of Aurelia aurita medusae in Kiel Bight and western Baltic. ICES J Mar Sci 51:359-367

Sharaf El Din SH (1977) Effects of the Aswan High Dam on the Nile flood and on the estuarine and coastal circulation pattern along the Mediterranean Egyptian coast. Limnol Oceanogr 22:194-207

Smith BS (1980) The estuarine mud snail Nassarius obsoletus: abnormalities in the reproductive system. J Molluscan Stud 49:247-256

Sousa WP (1984) The role of disturbance in natural communities. Annu Rev Ecol Sys 15:353-391

Spence SK, Hawkins SJ, Santos RS (1990) The mollusc Thais 
haemastoma - an exhibitor of 'imposex' and potential biological indicator of Tributyltin pollution. P.S.Z.N.I. Mar Ecol 11:147-156

Spight TM (1977) Latitude, habitat, and hatching type for muricacean gastropods. Nautilus 91:67-71

Stickle WB (1985) Effects of environment factor gradients on scope for growth in several species of carnivorous marine invertebrates. In: Gray JS, Christianson ME (eds) Marine biology of polar regions and effects of stress on marine organisms. John Wiley \& Sons, New York, p 155-166

Underwood AJ (1985) Physical factors and biological interac-

Editorial responsibility: William Stickle (Contributing Editor), Baton Rouge, Louisiana, USA tions: the necessity and nature of ecological experiments. In: Moore PG, Seed R (eds) The ecology of rocky coasts. Hodder \& Stoughton, London, p 372-390

Underwood AJ, Anderson MJ (1994) Seasonal and temporal aspects of recruitment and succession in an intertidal fouling assemblage. J Mar Biol Assoc UK 74:563-584

Tzur Y, Safriel UN (1978) Vermetid platforms as indicators of coastal movement. Isr J Earth Sci 27:124-127

Wootton JT (1994) Predicting direct and indirect effects: an integrated approach using experiments and path analysis. Ecology 75:151-165

Submitted: December 1, 1999; Accepted: December 18, 2000 Proofs received from author(s): July 13, 2001 